Canadian Journal of Higher Education Revue canadienne d'enseignement supérieur

Volume 47, No. 1, 2017, pages 153 - 170

\title{
Visioning as an Integral Element to Understanding Indigenous Learners' Transition to University
}

Amy Parent

Simon Fraser University

\begin{abstract}
This article focuses on high school to university transitions for Indigenous youth at universities in British Columbia, Canada. The study is premised on an Indigenous research design, which utilizes the concept of visioning and a storywork methodology (Archibald, 2008). The results challenge existing institutional and psychological approaches to transitions in revealing that they are deeply impacted by a variety of lived experiences and that a visioning process is vital to Indigenous youths' participation in university. The paper concludes with implications for practitioners working in educational and Aboriginal community-based settings.
\end{abstract}

\section{Résumé}

Cet article porte une attention particulière à la transition de l'école secondaire vers l'université des jeunes autochtones de la Colombie-Britannique, au Canada. L'études'appuie sur le modèle de la recherche autochtone, qui utilise le concept de la visualisation et sur une méthodologie basée sur le « storywork » (Archibald, 2008). Les résultats défient les approches institutionnelles et psychologiques des transitions en affirmant que celles-ci sont profondément affectées par la pluralité d'expériences vécues, et quel'intégration du processus de visualisation est essentielle à la participation des jeunes autochtones aux études universitaires., L'article conclut sur les répercussions possibles pour les praticiens de l'éducation et des communautés autochtones. 


\section{Author Introduction}

I acknowledge and thank the Musqueam, Squamish, and Tsleil-Waututh Nations for providing me with a space to study and teach on their ancestral, unceded, and overlapping territories. My mother's side of the family is Nisga'a from the House of Ni'isjoohl and we belong to the Ganada (Frog) Clan. On my father's side, I am French and German. My Nisga'a name is Nox Ayaa Wilt and I am a researcher and educator working at a Canadian university. My personal, community, and professional experiences guide my interest in the topic of Indigenous high school to university transitions.

\section{Introduction: Purpose and Research Question}

This article focuses on how visioning informs high school to university transitions for Indigenous youth at research-intensive universities in British Columbia, Canada. The empirical information for this paper is from a larger study on Indigenous students' high school to university transitions (Parent, 2014). This paper explores the following research question:

What challenges and successes do Aboriginal learners experience with Aboriginal early university promotion and Aboriginal university transition programs?

First, the article outlines the background and literature on two transitional pathwaysAboriginal early university promotion initiatives (AEUPIs) and Aboriginal university transition programs (AUTPs)-to provide a context for the reader, while also critiquing prevalent approaches. Second, the study's theoretical and methodological design-which incorporates visioning and storywork-is discussed (Archibald, 2008; Battiste, 2010; Cajete, 1994; HeavyRunner, 2009; Kirkness \& Barnhardt, 1991). Third, the results challenge existing institutional and psychological approaches to transitions (Astin, 1993; Falk \& Aitken, 1984; Holmes, 2005, 2006; Malatest \& Associates, 2004; Tinto, 1993) in revealing that transitions are deeply impacted by a variety of lived experiences and that a visioning process is vital to Indigenous youths' participation in university. The paper concludes with implications for educational practitioners and administrators.

\section{Literature Review}

There is little to no comprehensive literature available that views Aboriginal high school to university transitions from Indigenous theoretical perspectives. Some studies have utilized sociocultural theories to identify factors associated with Indigenous learners' successful completion of an undergraduate degree (i.e., family income; high school grades; family education level; family income; social integration with peers, faculty, and administrators; and academic integration) (Pascarella, Smart, \& Ethington, 1986; Pascarella \& Terenzini, 1991).

A number of other studies utilize a psychological framework in order to understand the adverse effects of transitions and changes on individual students. Some of these acknowledge that Aboriginal postsecondary learners may be at a greater "risk" of not "succeeding" and that changes to physical locations, the disruption of peer and family relationships, and adjustments to new academic and social expectations can negatively impact Aboriginal learners' transitions into postsecondary education. However, none of these studies focus specifically on university transition pathways. Although the studies highlight some 
of the tensions experienced by individual Aboriginal students, they often focus negatively on the deficits of individual learners as the primary reason for their failure to transition and do not acknowledge the many institutional barriers that create these difficulties (Falk \& Aitken, 1984).

The majority of research on the subject of transition stems from an institutional approach (Astin, 1993; Holmes, 2005, 2006; Korkow, 2008; Laverdure, 2009; Malatest \& Associates, 2002, 2004; Pickrell, 2008), which can problematically frame Aboriginal learners' transition in terms of issues of access, recruitment, admission, retention, and university completion rates. Therein, university transition is conceptualized as a linear process in which individuals apply to, enter, and acculturate into the institution. Often, the metaphor of a "pipeline" is erroneously used to describe Indigenous learners' transition process (Brayboy, Fann, Castagno, \& Solyom, 2012). From this standpoint, transition to university is usually regarded as a positive experience involving new opportunities for learners (Tinto, 1975, 1993). The acculturation process is seen to provide individual students with the knowledge needed to understand institutional norms, procedures, and expectations. In other words, Indigenous students are seen to intentionally assimilate into university cultures. This leaves little room for institutional accountability (Pidgeon, 2008a, 2008b) due to the hegemonic nature of the university. Consequently, the university all too often is required to take little, if any, responsibility for transforming its policies and practices to reflect the culture(s) and Indigenous knowledge (IK) of Aboriginal learners (Tierney, 1992).

Further, most institutional definitions of transition are regarded as positive because they are thought to establish continuity and familiarity during the high school to university transition and to build supportive connections between students and educators. Such definitions are problematic because most high schools are unfamiliar environments for Aboriginal youth in that curriculums, pedagogies, and institutional designs rarely take their needs and circumstances into account (St. Denis, 2010). The definitions therefore fail to accurately capture transition experiences. Having to transition from one unfamiliar environment to another often causes negative experiences and responses. If a student fails to "successfully" transition the way a "traditional student" is expected to, they become part of an institution's attrition rate and are labelled as having a deficit such as improper "academic preparation", "personal problems", "time management issues", "poor motivation", or "low achievement". These learners then become a statistic, and that statistic does not provide the context of colonialism that distinguishes Aboriginal learners from non-Aboriginal learners.

Most of the limited research that has been done on transitions tends to focus on the point when Aboriginal learners enter university, rather than viewing the multiple pathways and complex circumstances that shape their decisions to pursue higher education. This research is also generally predicated upon Western knowledge systems, and efforts to improve Aboriginal peoples' participation in universities remain limited by ongoing epistemological, socio-economic, political, and institutional challenges (Battiste, 2000; Royal Commission on Aboriginal Peoples, 1996; Truth and Reconciliation Commission, 2015). The challenges are particularly significant for Aboriginal youth in British Columbia (B.C.) (British Columbia Ministry of Advanced Education and Labour Market Development, 2008; Statistics Canada, 2005); these youth represent the fastest growing population in the province. In the $2009-10$ school year, $11.1 \%$ of Aboriginal high school graduates im- 
mediately transitioned to university, as compared to $25.9 \%$ of non-Aboriginal students (Heslop, 2012). ${ }^{1}$ There is clearly a need for higher education institutions to improve the resources and programs available to Aboriginal youth who will transition to university.

In recent years, Canadian universities have begun to develop a number of programs and services for Indigenous students, and the structural parameters of higher education are being modified by Indigenous knowledge, approaches, and practices (Archibald, Pidgeon, \& Hawkey, 2010; Association of Canadian Deans of Education, 2010; Stonechild, 2006). There are now a number of pathways along which Aboriginal learners can transition into university: early university promotion programs and initiatives, distance education, online learning, satellite programs, university transition programs, Aboriginal-controlled institution transfers, community college transfers, and direct entry from high school (Holmes, 2005, 2006). Without targeted attention to assist universities to critically respond to this need, the enrolment and graduation rates for Indigenous learners may not improve in any significant manner. More important, Aboriginal learners will not have positive wholistic ${ }^{2}$ learning experiences required to successfully nurture their transition to university.

\section{Aboriginal Early University Promotion Initiatives (AEUPIs) and Youth En- gagement}

Some universities across Canada are now beginning to offer a limited range of Aboriginal early university promotion initiatives and strategies aimed at encouraging Aboriginal youth to attend university. These include: Aboriginal high school career fairs, Aboriginal high school to university bridging summer programs (ranging from general to specific, focusing on particular disciplines), and hiring Aboriginal university recruitment officers to visit schools and communities (British Columbia Association of Aboriginal Friendship Centres, 2014; Indspire, 2017). Information obtained from the Association of Universities and Colleges of Canada (AUCC; now Universities Canada) recognized 15 existing high school summer programs (Parent, 2014). These initiatives and programs not only provide information about university but are intended to promote interest in higher education. To date, little research has been conducted about AEUPIs.

\section{Aboriginal University Transition Programs (AUTPs)}

University transition programs are the dominant pathway by which most Aboriginal learners enter university. ${ }^{3}$ These transition programs have been commonly created to respond to social inequalities, implement government policies, promote neo-liberal reconfigurations of education, and assess local demographic realities (Holmes, 2006). Students in these programs are conditionally admitted to university through an admissions process that utilizes personal references and interviews, and takes the life experiences of the applicant into account. Information obtained from the AUCC identifies 45 current Aboriginal transition programs at 29 of the 54 AUCC member universities in Canada (Parent, 2014). Most of these programs are designed to attract two student populations: (a) mature students who have been out of school for a long time and may not have a high school diploma, and (b) recent high school graduates who may not have the academic prerequisites for university entrance. 
Many scholars have argued that the $\mathrm{K}-12$ school system is problematic for Aboriginal learners because it often streamlines them into non-academic or vocational programs that prevent them from satisfying university entrance requirements (Aman, 2008; Battiste, 2000; Fann, 2004; Hunt-Jinnouchi, Hall, \& Lalonde, 2009; Kanu, 2006; Lee, 2007). To address this issue, transition programs enable these students to acquire the qualifications and skills necessary to apply for university. They may include a smorgasbord of required academic courses, an exploration of career possibilities, and First Nations and Indigenous study courses designed to enhance students' cultural knowledge and strengthen their identities (Holmes, 2006; Royal Commission on Aboriginal Peoples, 2006). Although the location, delivery, and funding of transition programs may differ significantly, their purposes are generally the same.

\section{Theoretical Design}

\section{Method}

This study's design was guided by Indigenous knowledge (IK) theorists (Archibald, 2008; Battiste, 2000; Nakata, 2007; Smith, 1999), who describe IK systems as ecological, relational, wholistic, pluralistic, experiential, communal, oral, and narrative-based. These scholars advance theories that seek to transform IK into a political and educational base of power that challenges the primacy of European approaches to knowledge. At the same time, their work forges new relationships between Indigenous and Western epistemologies and acknowledges that the inclusion of Aboriginal people in university requires the Indigenous/Western divide to be bridged rather than widened. Although Aboriginal communities and Nations represent diverse expressions of epistemology and ontology due to the uniqueness of place, language, culture, and colonialism, there are shared understandings held in common by all. These shared understandings allow for the development of Indigenous education to manifest in order to assist an individual to discover their unique gifts and purpose for journeying through life, community, land, and relationships. To this end, visioning is a concept that is grounded in Indigenous epistemologies and ontologies and was utilized for the study's theoretical framework.

The visioning process relies upon an individual's emotional, mental, spiritual, and physical experiences that lead to or are a consequence of the practices, ceremonies, and rituals of an Aboriginal community or Nation. According to Cajete (1994), "Such practices and contexts provide a framework for individuals and groups to teach and learn [from Indigenous knowledge and education] by exploring their inner psychology and their collective unconscious" (p. 39). Visioning is interconnected with wholism in an IK framework. Wholism provides an understanding of an individual's learning process as lifelong and life wide by encompassing the physical, emotional, mental, and spiritual aspects of the self and community. This understanding of human development is important because it allows us to see how wisdom and knowledge are imparted to individuals through a variety of life experiences and interactions, which take place both inside and outside of educational institutions and occur throughout one's lifetime. For example, within my Nation it is common practice for our hereditary tribal leadership comprising our Simgigat and Sigidimhaanak' (Chiefs, Elders, and Matriarchs) to identify and nurture the gifts of young people so that they may utilize them for the benefit of the community as they mature and begin to assume leadership responsibilities. This has been practised since time immemorial into present times and will continue into the future (K. Tait, personal communication, January 11, 2016). 
Universities also play a key role in validating and strengthening students' existing knowledge base and visioning process by providing rich environments, experiences, and multiple epistemological frameworks in their curriculum and practices so that Aboriginal learners may work toward the fulfillment of their gifts (i.e., unique skills and talents) and purposes. Several Indigenous authors have sought to develop and publish contemporary models of how this visioning process can be enhanced by educational institutions. Pueblo scholar and artist Cajete (2000) refers to visioning as "finding his or her face" (p. 183), which means through education, students can find a role, skill, or experience that will enable them to be fully heart-centred and to express their truest selves. Mi'kmaq academic Marie Battiste (2010) describes "nourishing the learning spirit" as a process "[that] guides our learning beyond family, community, and Elders, it is our own learning spirits who travel with us and guide us along our earth walk, offering us guidance, inspiration, and quiet unrealized potential to be who we are" (p. 1). Finally, HeavyRunner's (2009) research on Native American learners' college persistence defines visioning as "a creative exploration of choices [that assist] students to begin their journey into higher education, particularly for first generation students" (p. 126).

This study defines the mental images and ways of knowing and feeling that the youth shared in their interviews as "visioning" because it revealed AEUPIs' and AUTPs' capacity to clarify their higher education and life goals, and facilitate wholistic success. A visioning process is highly pertinent to Aboriginal university transition pathways because it provides a complex analysis of Indigenous learners' experience of higher education. It also provides new understandings about transition in order to assist higher education institutions to be epistemologically, culturally, and socially responsive to the needs of Indigenous learners.

\section{Indigenous Methodologies}

The increasing Indigenous presence in higher education has transformed research practices by foregrounding Indigenous knowledge and methodologies (Denzin, Lincoln, \& Smith, 2008; Kovach, 2010; Smith, 1999; Wilson, 2008). To this end, the study employed Archibald's (2008) storywork methodology, which articulates the principles of Aboriginal storytelling in educational research contexts. Kirkness and Barnhardt's (1991) "four Rs" of Aboriginal research (respect, relevance, reciprocity, responsibility) provided ethical guidelines for the research.

The entire study was framed by a bentwood box research design. This design had multiple functions for the larger study from which this article is derived. As a whole, the bentwood box was the symbolic container that housed the knowledge and stories from participants that were gathered in my research. As a multilayered metaphor, it illuminated the epistemological, theoretical, cultural, and personal explorations put forth in the research. Finally, the bentwood box image was used as a visual table of contents (with each one of the chapters of the study representing a side of the box and the seam that holds the box together (Parent, 2014). I am eternally grateful to Delgamuukw (Earl Muldon), a Gitxsan hereditary chief and master carver who helped me understand the process of creating a bentwood box. At the completion of the research, the bentwood box (filled with stories gathered from the research) was gifted back to Aboriginal communities and the universities.

The following methods were included: the creation of a guidance committee comprising various Indigenous people with extensive professional experience working with $\mathrm{Ab}$ - 
original youth in B.C.; open-ended, in-depth interviews with Aboriginal learners attending AEUPIs and AUTPs; interviews with staff from an AEUPI or AUTP; an interview with Delgamuukw an analysis of 54 university websites and AEUPI/AUTP materials; and a photo journal to trace research reflections.

\section{Site and Program Selection}

Five universities in B.C. were invited to participate in this project: University of British Columbia (Vancouver), University of British Columbia (Okanagan), University of Northern British Columbia, University of Victoria, and Simon Fraser University. Four Aboriginal early university promotion initiatives (CEDAR, Emerging Summer Scholars, Indigenous Mini University, Summer Science) and four Aboriginal university transition programs (Aboriginal Bridging Program, Aboriginal Pre-health Program, Access Program, and Northern Advancement Program) participated in this study.

\section{Participant Involvement}

I drew upon the knowledge and expertise of Aboriginal student service staff in the universities to aid in the recruitment and identification of Aboriginal students for interviews. I also emailed letters to former colleagues that I worked with through Supporting Aboriginal Graduate Enhancement (Graduate) and Supporting Aboriginal Graduate Enhancement (Undergraduate) initiatives and urban Aboriginal community listservs. Recruitment posters were also distributed through a snowball technique on Facebook. I arranged meetings with Aboriginal student service staff and program coordinators of the AEUPIs and AUTPs at each university to share information about my research and ask the best methods of recruitment at the institution. I was also invited to attend three of the AEUPIs and one of the AUTPs in person to meet with the youth and their families and answer any questions about the research process.

I recruited and interviewed eight Aboriginal youth aged 12-17 who were participating in an AEUPI and eight youth aged 17-24 who had participated (or were currently) in an AUTP at one of five research-intensive universities in B.C. ${ }^{5}$ Eleven full-time staff or faculty members who provided direct student services ${ }^{6}$ in an AEUPI or AUTP were recruited and interviewed..$^{7}$ Finally, an executive director ${ }^{8}$ of an Aboriginal youth organization was interviewed to learn more about community perceptions of Aboriginal youth engagement by universities in B.C.

\section{Analysis}

During analysis, the participants' interviews were grouped according to organizing themes which included a wholistic pattern, visioning, and Archibald's storywork as they are congruent with Indigenous methodology. Each interview was also analyzed and compared to earlier interviews, then placed in a comparative table to ensure a systematic analytic process. I also viewed photos I had taken on my research journey to provide visual reminders from the interviews. I then looked for emerging categories, while remaining open to other relationships and themes as they developed. I also analyzed the transcripts for experiences, elements, and concepts that were related to the visioning and storywork. Throughout this phase, I adopted each participant's special words to help preserve the meaning of their experiences, and I looked for cultural metaphors. 


\section{Results}

The study revealed that transitions are deeply impacted by a variety of lived experiences and that a visioning process is vital to Indigenous participation in university. Visioning-which is interconnected with Indigenous knowledge and theoretical understandings-was a key theme that emerged from my analysis of the interviews about the successes and challenges participants experienced in the programs. Other findings related to factors that support both transitions and institutional change and aim to improve Aboriginal youths' participation in higher education. These factors include wholistic student success, a sense of belonging, and generosity.

The study found that the visioning process was shaped by the youths' $\mathrm{K}-12$ experience; persons of influence; exploration of options; experience of transition programs, which often transformed their perception of higher education; and the need for role models to inspire them in their studies (Figure 1).

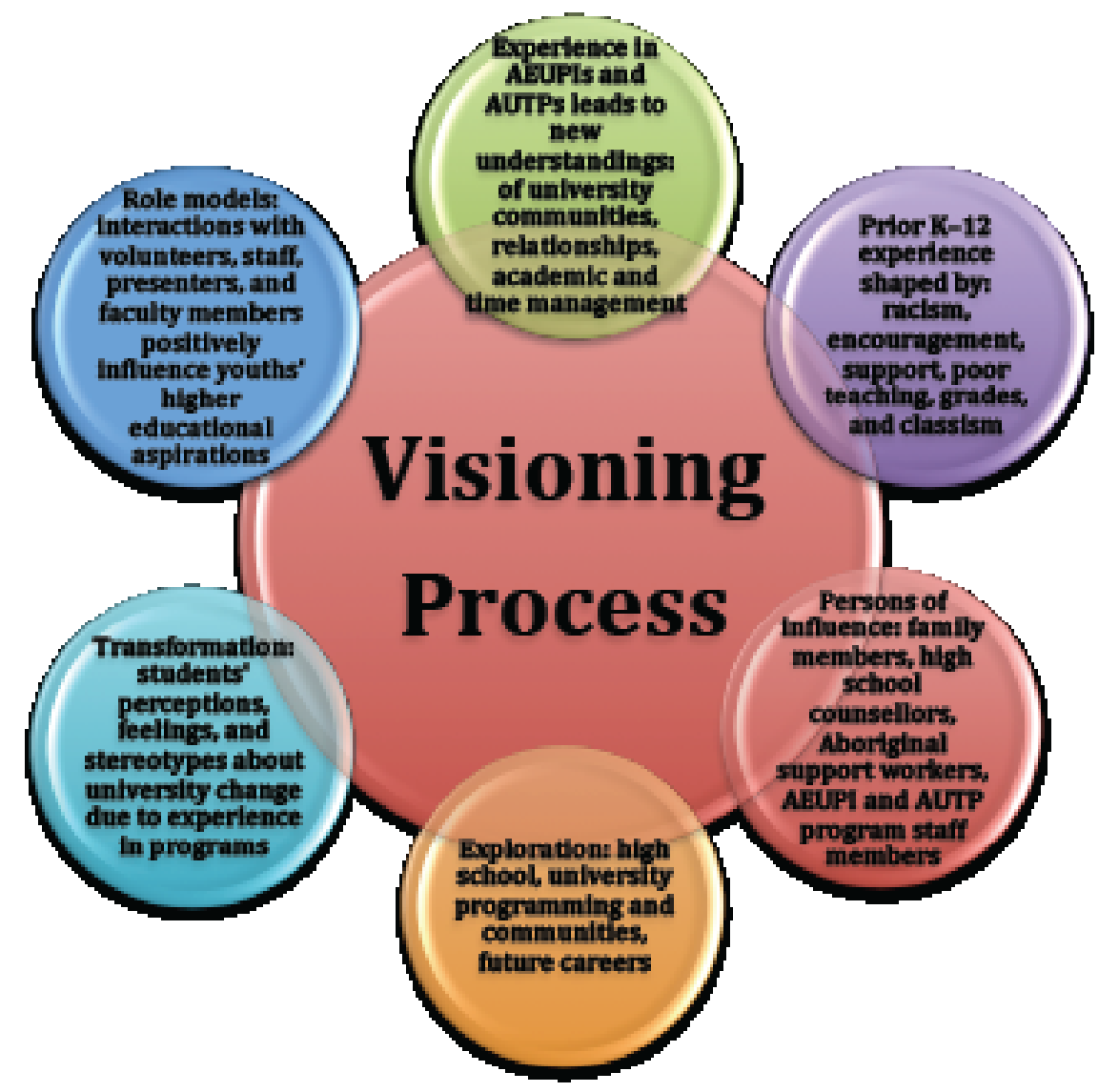

Figure 1. Indigenous youths' visioning process for university.

\section{Prior K-12 Experience}

Students' K-12 experience both hindered and facilitated their transition to university. The youth in this study had mostly negative experiences of the $\mathrm{K}-12$ system. As AEUPIs and AUTPs are different transitional pathways to university, it is not surprising that there were significant differences in students' responses. The AEUPIs clearly provided them 
with new skills and resources that helped them navigate their high school studies in a way that enabled them to directly transition to university. However, all eight of the AEUPI students noted that their commitment to doing well in high school was strengthened so that they could attend university after being in an AEUPI. Concurrently, their academic performance improved. Shannon, an AEUPI participant, explained that the program helped her to improve her mathematical skills and ensure that she would enter Calculus 12:

It's really good, like it helps me with my future with math and stuff, like if it weren't for this my grades wouldn't be up, like I think throughout the school year I've managed to keep a B or higher."

Some youth also noted that university volunteers in the programs "pushed" and inspired them to do better in high school.

The AUTP students reported experiencing significant challenges in their $\mathrm{K}-12$ schooling, including systemic racism, classism, bullying, and poor teaching. Unlike the AEUPI participants, the AUTP students did not have the benefit of a guided transition that could lead them to change their thoughts or feelings about their high school studies. Although previous negative $\mathrm{K}-12$ experiences significantly hindered these AUTP students' initial vision of university, they emphasized that it was more important to focus on what was working for them in university, rather than what had not worked in high school.

Therefore, the AEUPIs functioned as a positive pathway that addressed negative schooling experiences. The AUTP youth did not have this benefit and reported that negative secondary school experiences led them to enroll in their respective programs.

\section{Persons of Influence}

Parents, teachers, high school counsellors, First Nations support workers, and program staff-all were vitally important to the youth during their visioning process. Family members were cited as the most influential people within the AEUPI youths' circle of influence. Donna, an AEUPI participant, shared how her mom and a high school counsellor influenced her to attend the Summer Science program:

[My high school counsellor] told my mom, because she works with him. She is a math teacher's aide, and she takes kids out of the class and like helps them with their math and stuff. Yeah, she heard it from [my counsellor] and then she told me and then we went through the whole process of signing up and writing essays and all that kind of stuff. It was really cool.

AUTP participants shared stories about family members encouraging them to apply to a university transition program. For many, the encouragement and personal interest of AUTP staff, peers, and community members were turning points in their decision to attend university.

\section{Exploration}

The AEUPI participants frequently stated that they wanted to learn more about university and particular careers. Some students who had participated in more than one AEUPI were strategic in their program choice. For example, they attended one initiative that 
included an introduction to university life in its objectives and another that highlighted the science professions. An unexpected finding was that the two youngest AEUPI participants (who were in Grade 7 at the time of interview) chose to attend these initiatives in order to get a better understanding of high school from older youth participants and volunteers. As Angeline, an AEUPI participant, shared:

I just wanted to kind of experience what it was like to go to university and learn from the older kids because most of them are older than me. I wanted to know from them what it is like to be in high school.

As Angeline indicated, elementary-school-aged AEUPI participants felt that exploring how to be a successful high school and university student would be of great benefit when they looked beyond high school to the future. This also resonates with the intergenerational learning valued in Indigenous communities and connects strongly with a visioning process.

All of the AUTP participants had chosen their academic bachelor's degree programs as a result of participating in the AUTP, which had assisted them to learn about career options such as medicine, teaching, dentistry, arts, and First Nations studies. AUTP students spoke about the ways in which faculty and program staff had helped them to explore various academic and career pathways.

\section{Experience of Transition Programs}

The youth attending AEUPIs highlighted aspects of the programs that they valued, including learning about university communities, being better prepared to achieve high grades, and securing internship placements with Indigenous faculty. They also accentuated a number of relational experiences that made the AEUPIs particularly enjoyable, including making new friends, being mentored by staff and faculty, working with younger children, learning new social and communication skills, and participating in youth leadership development activities. As Lia, an AEUPI participant, shared:

It definitely made me a little more proud to be Native (like to be Indigenous) because usually like before I had always been like the only Native person in my class, in my school there were only like 20 Native kids out of like 1,500 , so it definitely made me a little more proud and it made me a little more curious to see, to learn more about the past and how it's changed.

AUTP students felt that their experiences in the program solidified their sense of belonging to the university and helped them to develop academic and time management skills.

\section{Transformation}

All of the AEUPI youths' stories revealed that the programs transformed their perceptions and feelings about university, making university a more likely option for them. One AEUPI participant, Eva, described the transformation:

Before, I didn't like school but since being in program, I like it. I thought university was a lot of studying and being in class. Going to university is kind of opening your minds to new ideas. It is sort of teaching you the different things you can be. 
Other students noted how the AEUPI assisted them to explore their future career paths. For example, Lia discussed how an AEUPI changed her mind about her future professional goals:

I wanted to become a music teacher before I came here, but I interned with Daniel Heath Justice at the English department, and he definitely sparked my interest in English and writing. So I am kind of shifting my goals to becoming a novelist.

Half of the youth in the study noted a number of diverse future career options that interested them as a result of their engagement with an AEUPI. AUTP students were not directly asked whether the program changed their choice of institution. However, an analysis of their collective stories revealed that all of the AUTP youth experienced some level of transformation in terms of their thoughts and feelings about becoming a university student.

\section{Role Models}

Analysis of the interviews showed that both groups of youth emphasized that role modelling impacted their visioning process. The AEUPI students felt that role models helped them succeed in their program, while the AUTP youth noted that a lack of visible role models hindered their success. Serenity, an AUTP student, stated:

They [the university] have to show that there are students just like them who came and went through the program and are now graduating with a bachelor degree and are going for their $\mathrm{PhD}$ and stuff. Like actually show the success stories, 'cause it's easy to just say on paper, oh, yeah, our success rate is this high and, um, so many students come through and so many people come out. Right? People on the reserve, they hear a lot of statistics, and it goes in one ear and goes out the other ear. For them to visually see something and actually experience it will make them want to come and do it, right?

This is a particularly salient point, as many Indigenous university students are the first in their family to attend university, and having role models in Aboriginal communities inspires more students to consider higher education.

\section{Discussion and Conclusion}

The youths' stories encompassed a number of themes that influenced their visioning process. This visioning process not only helped the youth to develop knowledge and skills that enhanced their high school endeavours, but also inspired them to believe that they could complete university and make a commitment to doing so. The process helped those students who were already in university to persist. However, the youth commonly considered their prior experience in the $\mathrm{K}-12$ system to be a hindrance to the visioning process because it limited their abilities to see themselves as future successful university students; this was particularly true for the AUTP youth. At the same time, the AEUPI youth acknowledged a number of persons within the $\mathrm{K}-12$ system who encouraged them to attend university and helped them with their applications. This support strengthened their capacity to handle negative $\mathrm{K}-12$ experiences and remain focused on their vision of attending university while working toward their lifelong and life-wide learning. 
The youth also indicated that learning about university through the real-life experience offered by the initiatives/programs was meaningful. In this sense, AEUPIs and AUTPs are very much aligned with Indigenous pedagogies that favour direct experience and "learning by doing." The AEUPI youth reported that their participation in the initiatives posed very few challenges. Most youth overcame any initial challenges by the end of the initiative and saw this as a major accomplishment that facilitated their growth and learning.

However, the AUTP youths' experiences seemed to be conditioned more by program objectives and the outside structure of the university than were the experiences of the AEUPI youth. Further, the study found that AEUPIs and AUTPs are deeply informed by competing and contradictory discourses (colonial, racist, liberal, neo-liberal, and Indigenous knowledge). All of the participants' accounts indicated that these discourses inevitably shaped their learning experiences. Most notably, the study discovered that youth who had no prior knowledge of their rich heritage were significantly impacted by AEUPIs' and AUTPs' provision of Indigenous knowledge and cultural understandings. In so doing, they affirm that Aboriginal people bring diverse viewpoints and experiences as they transition to the university. Although Indigenous peoples share many common denominators, our prior historical experiences are varied and nuanced, which can position us differently in the colonial present.

Further, both the AEUPIs and AUTPs provided youth with concrete opportunities to explore future academic and career pathways. All the AEUPI youth noted a significant transformation in their perceptions of university and felt that university became an option for them as a result of their participation in an initiative. These initiatives can therefore claim to have met their primary objective of promoting university education.

Ensuring that the youth were provided with opportunities to develop relationships with positive Aboriginal role models in the university was seen as a success factor by AEUPI youth. The AEUPI youth shared stories about the important leadership skills they developed as role models and mentors to younger youth in the initiatives, which in turn assisted them with their visioning process for university. This form of intergenerational learning also coincides with Indigenous pedagogical techniques that have been used to transmit knowledge and leadership values to younger generations for countless millennia (Archibald, 2008). However, most of the AUTP youth reported a lack of visible role models, which hindered their participation in university. This study's finding about role models corroborates several studies that highlight the importance of providing Aboriginal youth with strong mentorship and visible role models in order to support their higher education endeavours (Archibald et al., 2010; Kenny \& Ngaroimata Fraser, 2012; Pidgeon, 2008a).

The youths' stories indicate that the transition to higher education begins long before enrolment in university. Some of the youths' visioning processes began in elementary school. This finding directly challenges the institutional/psychological viewpoints that prevail in the literature (Astin, 1993; Terenzini, Lorang, \& Pascarella, 1981; Tinto, 1999). Further, these perspectives have not only shaped Aboriginal university transitions but have prevented universities from considering the ways in which persons of influence can encourage Aboriginal learners.To most Aboriginal students, university transition is a continual process of relationship building that is supported by a range of experiences that occur before, during, and after their entrance into higher education. Multiple groups, including families, communities, and Indigenous Nations, play a part in Aboriginal students' 
transitions and may in turn be impacted by the students' experience of higher education as well as the outcome of that experience (i.e., students giving back to their communities in a professional capacity). Acknowledging the individuals and groups that play an integral role in Indigenous learners' transition to university is therefore important to ensuring wholistic success for Indigenous communities (Pidgeon, Archibald, \& Hawkey, 2014).

The visioning process is integral to the discussion put forth in this paper because it augments learners' interest and commitment and helps them to build confidence in their capacity to transition from elementary school to high school to university and beyond. Further, analysis of the youths' stories indicates that their visioning processes actively directed their long-term aspirations for university and their self-determination priorities. The visioning process is a dimension of IK that can be incorporated not only into Aboriginal early university promotion initiatives and transition programs, but also-and more importantly-into high school and university curricula. As such, it provides a very real example of a learning activity that could contribute to the creation of cultural interfaces in educational settings (Nakata, 2007).

In addition, the visioning process is being utilized by educational practitioners who mentor Indigenous youth in an Aboriginal community-based educational setting as part of the knowledge mobilization aspects of the study. Youth in a community program were invited to consider their aspirations, hopes, and dreams for the future while being supported to continue exploring and strengthening their cultural identities. This type of programming was delivered by Aboriginal role models who strongly encourage the youth to consider attending university in order to assist their communities with self-determination priorities.

For administrators working in higher educational settings, ensuring that the university provides an ongoing and sustained funding commitment to Aboriginal early university promotion initiatives is necessary so that these initiatives may be expanded to critical subject areas that will encourage a higher number of Aboriginal youth to enter under-represented fields (such as science, technology, math, and engineering). Working directly with Indigenous families to support their children's transition to university is another concrete practice that can be utilized by university faculty and staff when working with Indigenous youth both prior to and during their enrolment in an AEUPI, an AUTP, or a university program.

This study addresses the growing body of literature and the recent Truth and Reconciliation Commission (2015) in Canada that call for higher education institutions to take greater responsibility for Indigenous higher education and recognize Indigenous frameworks such as visioning. It is critical for these institutions to look beyond institutional and statistical perspectives of transitions, recognize Indigenous learners' experience of transition, and examine how their organization, formal structures, resources, and patterns of association impact Aboriginal learners' persistence and wholistic success in these institutions (Archibald et al., 2010; HeavyRunner, 2009; Pidgeon, 2008a, b; Pidgeon et al., 2014; Kuokkanen, 2007). If higher educational institutions want to fully engage Aboriginal learners, it is imperative for them to understand that multiple world views and knowledge systems coexist. To this end, the visioning process offers universities an opportunity to apply Indigenous knowledges to policies, programs, practices, and services that are meaningful to Aboriginal university transitions. In doing so, it challenges educational institutions to strategically support Aboriginal learners' transitions. As Pidgeon et al. (2014) aptly point out, failing to do so clearly indicates a lack of institutional commit- 
ment and gives Aboriginal students the message that "the academy is not interested or concerned about their involvement, educational needs, Indigenous knowledges, philosophies, and cultural integrities" (p. 3).

Ultimately, the stories of the youths in this study as well as the insights they offered suggest that the future of AEUPIs/AUTPs can be a promising one if universities make a genuine commitment to Aboriginal learners, take heed of their knowledges, experiences, and stories, and become willing to implement practical and epistemological changes that make higher education truly inclusive of Indigenous communities.

\section{Notes}

1. While the research pertaining specifically to Aboriginal high school learners in Canada is still developing, the experiences of Native American, African American, and Hispanic groups provides insight to experiences similar to those of Aboriginal students. For example, this body of literature has shown that children who aspire to attain higher education are commonly supported and encouraged by their parents (Hossler, Braxton, \& Coopersmith, 1989; Hossler, Schmit, \& Vesper, 1999; McDonough, 1997). Fann (2004) suggests that many Native American parents have not attended college or university and are therefore often unable to provide the critical information that is necessary to help their children prepare and become eligible for university, even though they share a desire for their children to succeed in the educational realm. As a result, many Indigenous families must rely upon the $\mathrm{K}-12$ system, universities, and Aboriginal organizations to provide their children with information about university preparation.

2. Wholism denotes a learner's physical, intellectual, emotional, and spiritual needs are met by their schooling and life experiences. Wholism is spelled in this way to highlight the importance of educating the whole person within an Indigenous knowledge framework and to separate the term from a Western liberal humanistic understanding of "holism," which is secular.

3. Educational institutions and branches of government give these programs a variety of names: university and college entrance programs, access programs, transition programs, and bridging programs.

4. Delgamuukw's interview was formative to helping me envision my methodological design and understandings of the bentwood box. A separate article from the larger research study is in process in order to discuss the unique methodology from the study in greater depth.

5. In total 17 youth were recruited and interviewed. However, one AUTP youth was interviewed and decided to withdraw her name from the study for undisclosed reasons.

6. Direct supervision included instruction, recruitment, advising, or mentoring in an AEUPI or AUTP.

7. I felt it was important to interview at least one staff person, faculty, or administrator from each AEUPI and AUTP. These participants were recruited upon their interest and willingness to speak to the purpose and impacts of their respective programs. All staff persons, faculty, and administrators that I approached agreed to be interviewed for the study.

8. I felt it was important to interview this person given the fact that over 6,00o Indigenous youth per year have accessed the organization she leads. This interview helped to 
provide a balanced perspective of the university's community engagement strategies with Indigenous youth, as well as the impact of the AEUPIs and AUTPs on the lives of urban Aboriginal Indigenous youth.

\section{References}

Aman, C. (2008). Aboriginal students and school mobility in British Columbia public schools. Alberta Journal of Educational Research, 54(4), 365-377.

Archibald, J. (2008). Indigenous storywork: Educating the heart, mind, body and spirit. Vancouver: UBC Press.

Archibald, J., Pidgeon, M., \& Hawkey, C. (2010). Aboriginal transitions: Undergraduate to graduate (Phase 1 Final Report). Retrieved from British Columbia Ministry of Advanced Education website: http://www.aved.gov.bc.ca/aboriginal/docs/educator-resources/UBCATRF-I.pdf

Association of Canadian Deans of Education. (2010). Accord on Indigenous Education. Retrieved from http://www.cssescee.ca/docs/acde/ACDE_Accord_on_Indigenous_ Education.pdf

Astin, A. (1993). What matters in college? Four critical years revisited. San Francisco, CA: Jossey-Bass.

Battiste, M. (Ed.) (2000). Reclaiming Indigenous voice and vision. Vancouver: UBC Press.

Battiste, M. (2010). Nourishing the learning spirit. Education Canada, 5o(1). Retrieved from Canadian Education Association website: http://www.cea-ace.ca/sites/cea-ace.ca/ files/EdCan-2010-v50-n1-Battiste.pdf

Brayboy, B., Fann, A., Castagno, A., \& Solyom, J. (2012). Postsecondary education for American Indian and Alaska Natives: Higher education for nation building and self-determination (ASHE Higher Education Report, 37[5]). San Francisco, CA: Wiley/ Jossey-Bass.

British Columbia Association of Aboriginal Friendship Centres. (2014). Gathering Our Voices Aboriginal Youth Conference [Web page]. http://www.bcaafc.com/ newsandevents/gathering-our-voices

British Columbia Ministry of Advanced Education and Labour Market Development. (2008). Aboriginal report: Charting our path. Retrieved from Document1http://www. aved.gov.bc.ca/aboriginal/documents/Aboriginal_Indicator_Report-Oct2008.pdf

Cajete, G. (1994). Look to the mountain: An ecology of Indigenous education. Durango, CO: Kivaki Press.

Cajete, G. (2000). Indigenous knowledge: The Pueblo metaphor of Indigenous education. In M. Battiste (Ed.), Reclaiming Indigenous voice and vision (pp. 181-191). Vancouver: UBC Press.

Falk, D. R., \& Aitken, L. P. (1984). Promoting retention among American Indian college students. Journal of American Indian Education, 23(2), 24-31. 
Fann, A. (2004). Forgotten students: American Indian high school students' narratives on college going. Prepared for the UC Berkeley Center for the Study of Higher Education. Retrieved from U.S. Department of Education website: http://www2.ed.gov/ rschstat/research/pubs/oieresearch/conference/fann_200504.pdf

HeavyRunner, I. (2009). Miracle survivor (Pisatsikamotaan): An Indigenous theory on educational persistence grounded in the stories of tribal college students (Unpublished doctoral dissertation). University of Minnesota, Minneapolis.

Heslop, J. (2012). Research results from the Student Transitions Project. Victoria, BC: Ministry of Advanced Education.

Holmes, D. (2005). Embracing differences: Post-secondary education among Aboriginal students, students with children and students with disabilities. Montreal, QC: Canadian Millennium Foundation.

Holmes, D. (2006). Redressing the balance: Canadian university programs in support of Aboriginal students. Report prepared for the Association of Universities and Colleges of Canada, Ottawa. Retrieved from the Nicola Valley Institute of Technology website: http://www.nvit.ca/docs/redressing\%20the\%2obalance\%20canadian\%2ouniversity\%20 programs\%20in\%20support\%20of\%20aboriginal\%20students.pdf

Hossler, D., Schmit, J., \& Vesper, N. (1998). Going to College: How social, economic, and educational factors influence the decisions students make. Baltimore: John Hopkins University Press.

Hunt-Jinnouchi, F., Hall, B. L., \& Lalonde, C. (2009). Transitions from Aboriginalcontrolled post-secondary institutes to public post-secondary institutions (Final Research Report). Prepared by the Office of Indigenous Affairs, University of Victoria, in partnership with the Indigenous Adult \& Higher Learning Association. Retrieved from British Columbia Ministry of Advanced Education website: https://www.aved.gov.bc.ca/ aboriginal/docs/educator-resources/UVIC-ATRF.pdf

Indspire. (2017). Soaring: Indigenous youth career conferences [Web page]. Retrieved from http://www.indspire.ca/for-students/career-planning/

Kanu, Y. (2006). Getting them through the college pipeline: Critical elements of instruction influencing school success among native Canadian high school students. Journal of Advanced Academics, 18(1), 116-145.

Kenny, C., \& Ngaroimata Fraser, T. (Eds). (2012). Living Indigenous leadership: Native narratives on building strong communities. Vancouver: UBC Press.

Kirkness, V. J., \& Barnhardt, R. (1991). First Nations and higher education: The four R's-respect, relevance, reciprocity, responsibility. Journal of American Indian Education, 30(3), 1-15.

Korkow, J. (2008). Native American success in college (Unpublished doctoral dissertation). University of South Dakota, Vermillion.

Kovach, M. (2010). Indigenous methodologies: Characteristics, conversations, and contexts. Toronto, ON: University of Toronto Press. 
Kuokkanen, R. (2007). Reshaping the university: Responsibility, Indigenous epistemes and the logic of the gift. Vancouver: UBC Press.

Laverdure, A. (2009). Characteristics of successful First Nations college students: A mixed methods study (Unpublished doctoral dissertation). North Dakota State University, Fargo.

Lee, T. S. (2007). Successes and challenges in higher education transitions. Tribal College Journal of American Indian Higher Education, 19(1), 34-35.

Malatest \& Associates. (2002). Best practices in increasing Aboriginal postsecondary enrolment rates. Retrieved from Council of Ministers of Education, Canada website: http://www.cmec.ca/Publications/Lists/Publications/Attachments/49/malatest.en.pdf

Malatest \& Associates. (2004). Aboriginal peoples and post-secondary education: What educators have learned. Prepared for the Canadian Millennium Scholarship Foundation. Retrieved from Turtle Island Native Network website: http://www. turtleisland.org/education/postseced.pdf

McDonough, P.M. (1997). Choosing colleges: How social class and schools structure opportunity. New York: State University of New York Press.

Nakata, M. (2007). The cultural interface. Australian Journal of Indigenous Education, 36(Supp.), 7-14. Retrieved from http://c.ymcdn.com/sites/www.weraonline. org/resource/resmgr/symposiamembermeetings/2010-siep-marti_nakata_ajie.pdf

Parent, A. (2014). Bending the box: Learning from Indigenous students transitioning from high school to university (Doctoral dissertation). Retrieved from https://open. library.ubc.ca/

Pascarella, E. T., Smart, J. C., \& Ethington, C. A. (1986). Long-term persistence of twoyear college students. Research in Higher Education, 24(1), 47-71.

Pascarella, E. T., \& Terenzini, P. T. (1991). How college affects students. San Francisco, CA: Jossey-Bass.

Pickrell, A. (2008). An evaluation of the effectiveness of a postsecondary transition program for Aboriginal students (Master's thesis). Retrieved from http://research. library.mun.ca/8675/

Pidgeon, M. E. (2008a). It takes more than good intentions: Institutional accountability and responsibility to higher education (Doctoral dissertation). Retrieved from https://open.library.ubc.ca/

Pidgeon, M. (2008b). Pushing against the margins: Indigenous theorizing of success and retention in higher education. Journal of College Student Retention, 1O(3), 339-360.

Pidgeon, M., Archibald, J., \& Hawkey, C. (2014). Relationships matter: Supporting Aboriginal graduate students in British Columbia, Canada. Canadian Journal of Higher Education, 44(1), 1-21.

Royal Commission on Aboriginal Peoples. (1996). Report of the Royal Commission on Aboriginal Peoples, Volume 3: Gathering Strength. Retrieved from Library and Archives Canada website archive: http://www.collectionscanada.gc.ca/ webarchives/20071115053257/http://www.ainc-inac.gc.ca/ch/rcap/sg/sgmm_e.html 
Smith, L. T. (1999). Decolonizing methodologies: Research and Indigenous Peoples. Dunedin, New Zealand: University of Otago Press.

Statistics Canada. (2006). Profile of Aboriginal Children, Youth and Adults. Retrieved from http://www5.statcan.gc.ca/bsolc/olc-cel/olc-cel?catno=89-635-X\&lang=eng

St. Denis, V. (2010). A study of Aboriginal teachers' professional knowledge and experience in Canadian schools. Retrieved from Canadian Teachers' Federation website: https://www.ctf-fce.ca/Research-Library/ABORIGINAL-Report2010-WEB.pdf

Stonechild, L. (2006). The new buffalo: The struggle for First Nations higher education. Winnipeg: University of Manitoba Press.

Terenzini, Lorang, \& Pascarella. (1981). Predicting freshman persistence and voluntary dropout decisions: A replication. Research in Higher Education, 15(2), 109-127.

Tierney, W. G. (1992). An anthropological analysis of student participation in college. Journal of Higher Education, 63(6), 603-618.

Tinto, V. (1975). Dropout from higher education: A theoretical synthesis of recent research. Review of Educational Research, 45(1), 89-125.

Tinto, V. (1993). Leaving college: Rethinking the causes and cures of student attrition (2nd ed.). Chicago, IL: University of Chicago Press.

Tinto, V. (1999). Taking retention seriously: Rethinking the first year of college. NACADA Journal, 19(2), 5-9.

Truth and Reconciliation Commission. (2015). Honouring the truth, reconciling for the future: Summary of the final report of the Truth and Reconciliation Commission of Canada. Retrieved from http://www.trc.ca/websites/trcinstitution/File/2015/Findings/ Exec_Summary_2015_05_31_web_o.pdf

Wilson, S. (2008). Research is ceremony: Indigenous research methods. Halifax, NS: Fernwood Publishing.

\section{Contact Information}

Amy Parent

Simon Fraser University

aparent@sfu.ca

Amy Parent is a member of the Nisga'a Nation on her mother's side and is German and French on her father's side of the family. She is an assistant professor in the Faculty of Education at Simon Fraser University, where she seeks to build reciprocal relations between the university and Aboriginal communities. Her research and teaching interests include Indigenous higher education, Indigenous knowledge systems and methodologies, Aboriginal youth studies, and integrating Indigenous content into teacher education. 